\title{
Urgences
}

\section{Le matin fragile ou Heavy Petal}

\section{Richard Corriveau}

Numéro 15, octobre 1986

Épigraphiques

URI : https://id.erudit.org/iderudit/025290ar

DOI : https://doi.org/10.7202/025290ar

Aller au sommaire du numéro

Éditeur(s)

Urgences

ISSN

0226-9554 (imprimé)

1927-3924 (numérique)

Découvrir la revue

Citer ce document

Corriveau, R. (1986). Le matin fragile ou Heavy Petal. Urgences, (15), 22-22.

https://doi.org/10.7202/025290ar d'utilisation que vous pouvez consulter en ligne.

https://apropos.erudit.org/fr/usagers/politique-dutilisation/ 


\section{Richard Corriveau LE MATIN FRAGILE OU HEAVY PETAL}

La mémoire est fragile et allumée comme un coquelicot dans le brouillard.

Paul Claudel, cité par Julos Beaucarne: "Pointe aux Anglais" (microsillon Le vélo volant)

Le squelette lent à venir a peur tout à coup des ombres qui remuent L'alarme de la peau triste résonne sur ses toasts brûlées Il interroge l'éphémère qui dure au gré des marées nausées des maux de ventre pleine lune et qui nous transmet transforme on ne sait où on ne sait vers qui Il pense à l'aveugle invisible qui fait des noeuds dans ses cordes vocales comme d'autres font avec les tripes pâles Puis il préfère s'en tenir au café et explose quelques décibels en trop 